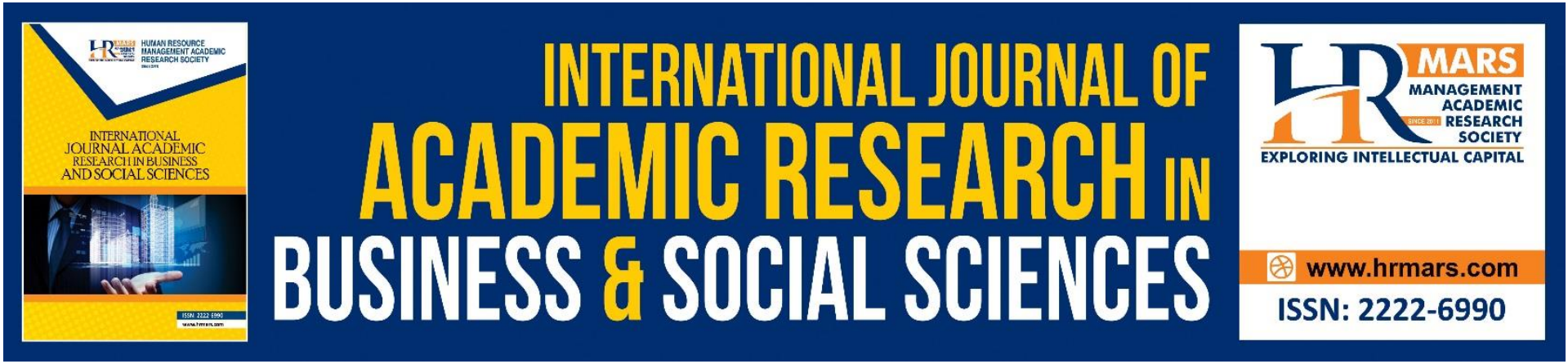

\title{
Exploring Learning Activities in Teaching Islamic Education in Preschool Classroom
}

Nor Bahriyah Saptari, Nurul Atiqah Satari \& Suziyani Mohamed

To Link this Article: http://dx.doi.org/10.6007/IJARBSS/v11-i2/8442 ～DOI:10.6007/IJARBSS/v11-i2/8442

Received: 29 December 2020, Revised: 23 January 2021, Accepted: 10 February 2021

Published Online: 25 February 2021

In-Text Citation: (Saptari et al., 2021)

To Cite this Article: Saptari, N. B., Satari, N. A., \& Mohamed, S. (2021). Exploring Learning Activities in Teaching Islamic Education in Preschool Classroom. International Journal of Academic Research in Business and Social Sciences, 11(2), 717-726.

Copyright: (c) 2021 The Author(s)

Published by Human Resource Management Academic Research Society (www.hrmars.com)

This article is published under the Creative Commons Attribution (CC BY 4.0) license. Anyone may reproduce, distribute, translate and create derivative works of this article (for both commercial and non-commercial purposes), subject to full attribution to the original publication and authors. The full terms of this license may be seen

at: http://creativecommons.org/licences/by/4.0/legalcode

Vol. 11, No. 2, 2021, Pg. 717 - 726

http://hrmars.com/index.php/pages/detail/IJARBSS

JOURNAL HOMEPAGE

Full Terms \& Conditions of access and use can be found at http://hrmars.com/index.php/pages/detail/publication-ethics 


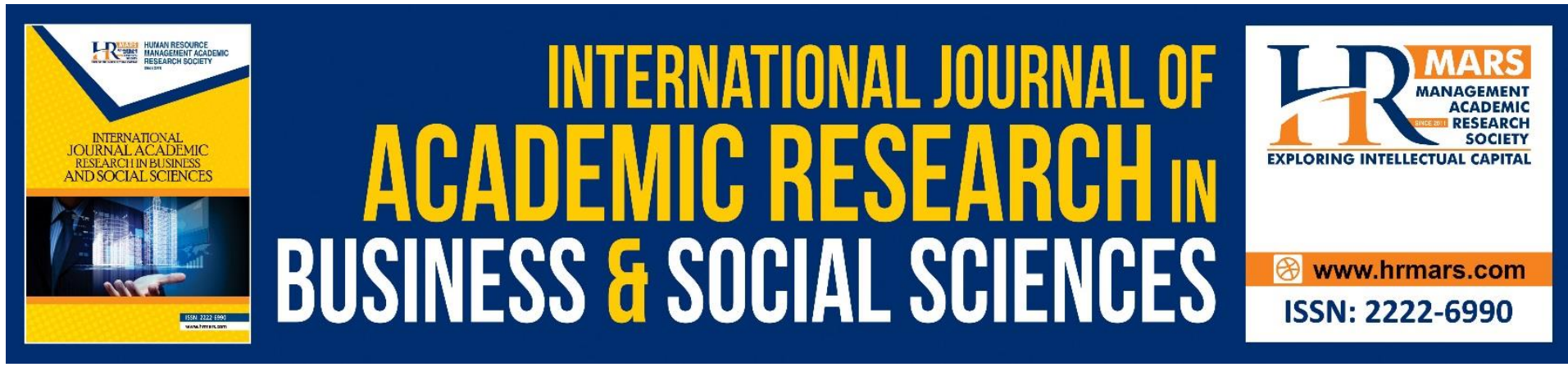

\title{
Exploring Learning Activities in Teaching Islamic Education in Preschool Classroom
}

\author{
Nor Bahriyah Saptari ${ }^{1}$, Nurul Atiqah Satari² \& Suziyani \\ Mohamed ${ }^{3}$ \\ ${ }^{1,3}$ Faculty of Education Universiti Kebangsaan Malaysia, ${ }^{2}$ Faculty of Human Development \\ Universiti Pendidikan Sultan Idris
}

\begin{abstract}
In Malaysia, Islamic Education is one of the subjects listed in Standard National Preschool Curriculum has listed various methods as guidelines for preschool teachers for the teaching and learning process. Methods available include inquiry-based learning, integrated, multithemed learning, project-based learning, mastery learning, contextual learning and learning based on intelligence diversity. Various methods used by teachers can affect the PdP of preschool Islamic Education subject. Teachers need to complete the method according to the content in the subject that can attract students and practice it. The purpose of this study is to explore the learning activities implemented in the teaching Islamic Education subject. This study was conducted based on a qualitative case study using semi-structured interview protocol questions as a research instrument. The study sample consisted of three teachers who teach preschool Islamic Education subject. This study was conducted in a private preschool in the district of Hulu Langat. The findings of the study exhibited that singing and storytelling activities as well as good examples from teachers were the activities often used and more effective on children. The implications of this study can benefit teachers in implementing more effective learning activities for preschool Islamic Education subject. In addition, those involved in the implementation of Standard National Preschool Curriculum can get courses or programs on the effective learning methods for this subject. Thus, problems related to the knowledge and weaknesses of teachers can be overcome with the exposure of more effective and easy to implement methods.
\end{abstract}

Keywords: Learning Activitiy, Storytelling, Singing, Preschool, Islamic Education

\section{Introduction}

Islam is an official religion in Malaysia. Due to this status, Islam Education subject embedded into the Malaysian education system in every level of education. This subject is compulsory for all Muslim. As for non-muslim, they will register into the Moral Education subject. Islamic Education subject taught in preschool, primary, secondary and tertiary level of education. At preschool education level, Islamic Education subject has been stated explicitly in the Standard National Preschool Curriculum. Standard National Preschool 
Curriculum contains six pillars, namely (i) communication; (ii) spirituality, attitudes and values; (iii) personal skills, (iv) physical and aesthetics (v) science and technology; and (vi) humanity.

Islamic Education is one of the subjects under Spirituality, Attitude and Values pillar. This pillar aims to enhance children knowledge regarding appreciation of religious practices, beliefs, attitudes and values (Standard National Preschool Curriculum, 2017). While the Islamic Education subject underlined five learning objectives namely (i) basic learning of the Quran and Jawi; (ii) shaping faith; (iii) basis of worship; (iv) nurturing of pure values and morals; and (v) knowledge and introduction to the story of the Prophet Muhammad SAW. National Standard for Preschool Education allocate 120 minutes/week for teaching and learning Islamic Education.

Islamic Education is a starting point for children to deepen their religious knowledge. Besides, Islamic Education is crucial so that the guidelines derived from revelation can be translated in the form of application in line with the role of Islam as a way of life (Rosmadi \& Isa, 2019; Nursafra et al., 2016; Hoot, Szecsi \& Moosa, 2003). Therefore, teachers carry a great responsibility in helping children to enhance their knowledge about Islam through Islamic Education subject (Maimun, Wan \& Mohd, 2017). Hence, the teacher needs to be more cautious in choosing the appropriate teaching and learning approach and strategy that can benefit the children (Masnan et. al., 2019). Thus, teachers need sufficient knowledge and skills to perform their responsibilities as an educator and be a good role model for children. They must be able to implement fun teaching in the preschool classroom.

There are studies highlighted teachers' practice in teaching Islamic Education subject in the preschool classroom. The research emphasised that planning and implementing an appropriate classroom activity is vital in determining the desired learning outcomes (Abd Karim, Baharudin \& Hamdani, 2019; Norizah, Abu Bakar \& Zaharah, 2014), especially at the preschool level. Previous studies show majority preschool teachers perceived that children learn fast through edutainment (Ramlah, Nor and Siti, 2016). Term edutainment is referring to the combination of education and entertainment element in teaching young children. This edutainment activity is easily implemented and widely used by preschool teachers. Besides edutainment, preschool teachers also often used modelling in teaching Islamic Education (Sofia, Kamarul \& Muhammad, 2016). The teacher will demonstrate and show a good example to encourage and motivate children to imitate. Among the noble morals practised are love, sincerity, advice, prudent in reprimanding mistakes, gradual teaching and knowledge practice.

In line with the Industrial Revolution 4.0, the usage of technology also introduced in teaching and learning Islamic Education. The teacher starts using gadget and application in their preschool classroom. Teacher starts used multimedia language game applications to cultivate childrens' interest and motivation towards Jawi and al-Quran learning (Nur et al. 2017). Therefore, the purpose of this study is to explore the learning activities implemented by preschool teachers in teaching Islamic Education subject.

\section{Problem Statement}

Islamic Education as stated in National Standard of Preschool Curriculum is based on spirituality, attitude and values to know more about Allah SWT and Islam, five pillars of Islam, six pillars of faith, application of pure values in oneself and build noble morals as well as being able to recognize and memorize Jawi letters and short Quran verses. The effectiveness of a learning starts from the teacher who delivers the contents and the teacher needs to diversify the teaching and learning strategies, especially for Islamic Education subject. 
A study conducted by Nur et al. (2017) discovered that there are issues related to children who still do not master the Quran which also affect the mastery of Jawi. This may be because there are still few teachers who lack mastery of pedagogy and teaching aids during the teaching and learning process (Hambal, 2020). The knowledge of teachers on teaching pedagogy is very important in implementing teaching and learning to attract students and be effective on student learning (Masnan et al., 2019).

Apart from that, there are also issues related to Islamic Education teachers that do not stimulate childrens' thinking. According to Nursafra et al. (2016), the ability of teachers as critical thinkers should be developed first so that it will be easier for them to polish childrens' skills. This could also be attributed to the preschool Islamic Education teachers who need to encourage students to think of cause and effect when doing something good or bad (Rosmadi \& Isa, 2019; Mohamed, 2017).

Furthermore, Mohd and Ahmad (2016) explained that the teaching practice of teachers should emphasize the study of the Quran to ensure the implementation, appreciation and practice by childrens in accordance with the requirements of Allah SWT. Student learning must be carried out continuously not only at school but also at home. Teachers should play an important role for students to cultivate an ongoing interest in learning religious knowledge as most of the time children are in school (Hambal, 2020; Hoot, Szecsi \& Moosa 2003).

For preschools under the ministry, most of the teachers who teach Islamic Education are expert in that field, and also teach the same subject for level 1 or level 2 of primary schools. They have no background in early childhood education and acquire knowledge of preschool from courses or programs organized. As reported by Sofia and Kamarul (2016), the participants in their study revealed that they obtained early child education knowledge through Postgraduate Teaching Course, practicum training, Micro Teaching Course and knowledge sharing among other Islamic Education teachers during practicum. The teachers have more knowledge of Islamic religious education compared to those of private preschool teachers.

\section{Methodology}

The responses required in this study were the description of the teacher preferences in conducting an activitities in teaching Islamic Education. Therefore, this study used a qualitative approach of a case study based on exploratory methods. A case study is a study that investigates contemporary phenomena in the context of real life, especially when the boundary between phenomena and context is not clearly proven (Yin, 1994). This design was used to explore the activities implemented by preschool teachers in the Islamic Education subject.

\section{Study Location and Sampling}

The study was conducted at the district of Hulu Langat, Selangor. The population for this study was teachers from private preschools in Hulu Langat district. The purposive sampling technique used to determine the participants of this study. Three criteria have been set in selecting participants. Participants in this study must have; (i) at least 10 years teaching experience in preschool; (ii) attended training on Standard National Preschool Curriculum 2017; and (iii) at least five-year experience in teaching Islamic Education subject at the preschool level. Three participants identified and involved in this study. 
Table 1 shows that all participants met the criteria. Three teachers have early childhood education background; one teacher was a diploma holder, and two teachers were degree holders. Meanwhile, the teaching experiences in preschool and preschool Islamic Education subject were the same. The teachers teach according to class and not according to subject. In other words, the teachers teach all subjects in one class, including Islamic Education subject. All teachers have attended the revised Standard National Preschool Curriculum course 2017.

Table 1: Demographics of participants in the study

\begin{tabular}{llccc}
\hline Participants & $\begin{array}{l}\text { Education } \\
\text { background }\end{array}$ & $\begin{array}{c}\text { Preschool } \\
\text { teaching } \\
\text { experience }\end{array}$ & $\begin{array}{c}\text { Preschool Islamic } \\
\text { Education } \\
\text { teaching } \\
\text { experience }\end{array}$ & $\begin{array}{c}\text { Attend revised } \\
\text { Standard } \\
\text { National } \\
\text { Preschool } \\
\text { Curriculum } \\
\text { course 2017 }\end{array}$ \\
\hline $\mathbf{G 1}$ & $\begin{array}{l}\text { Diploma in Early } \\
\text { Childhood } \\
\text { Education } \\
\text { Bachelor of Early } \\
\text { Childhood } \\
\text { Education } \\
\text { Bachelor of Early } \\
\text { Childhood } \\
\text { Education }\end{array}$ & 11 years & 11 years & Yes \\
$\mathbf{G 3}$ & 13 years & 13 years & Yes \\
\hline
\end{tabular}

\section{Instrument}

This research instrument used in this study was based on semi-structured interview questions comprising two parts. The first part included the background of participants and the second part was constructed based on the objectives of the study which is to explore the learning activities implemented, teachers' views on learning activities and problems faced by teachers in teaching Islamic Education for preschooler.

\section{Data Collection and Analysis Procedures}

Data collection process conducted using semi-structured interviews questions. Interviews session was conducted face-to-face for 40 minutes to 1 hour for each participant. The participants informed the purposes of the interview and aware that the interview session will be recorded. Some of the interview questions related to teacher knowledge and learning activities were adapted from previous research by Sofiah and Kamarul (2016) as references. An interview protocol also developed to facilitate the interview session. The interviews transcribed into a verbatim format. The themes and sub-themes were further analyzed and elaborated. In qualitative research, maintained accuracy, interpretation and analysis and the research findings in terms of reliability or trustworthiness are very important (Creswell \& Poth, 2018). Therefore, the interview instrument validated by two experts in the field of preschool education. The results of the interview transcripts were re-verified by the three preschool teachers on the validity of the information recorded. 


\section{Findings}

Table 2 shows a summary of the findings obtained from the interview. There were two themes outlined in the research questions, namely, (i) learning activities often implemented; and (ii) problems arise during the teaching of Islamic Education. There were several sub-themes withdrawn from the theme. The sub-themes identified from learning activities theme are singing, storytelling and set up a good example. While the sub-themes for problems faced in teaching Islamic Education are the lack of knowledge about Islam, difficulties in pronouncing of Jawi letters and correcting the Quran reading by childrens. These could be due to the appreciation in the recitation of the Quran.

Table 2: Summary of Findings

\begin{tabular}{|c|c|c|}
\hline Research questions & Theme & Sub-theme \\
\hline \multirow{5}{*}{$\begin{array}{l}\text { What are the learning } \\
\text { activities used by the } \\
\text { teachers for preschool } \\
\text { Islamic Education } \\
\text { subject? }\end{array}$} & \multirow{3}{*}{$\begin{array}{l}\text { Learning activities often } \\
\text { implemented in teaching } \\
\text { Islamic Education subject. }\end{array}$} & Singing \\
\hline & & Storytelling \\
\hline & & Modelling \\
\hline & \multirow[t]{2}{*}{$\begin{array}{l}\text { Problems that arise during } \\
\text { teaching Islamic Education }\end{array}$} & $\begin{array}{l}\text { Lack of knowledge in correcting } \\
\text { pronunciation of Jawi letters }\end{array}$ \\
\hline & & $\begin{array}{l}\text { Difficult to correct childrens' } \\
\text { pronunciation while reading and } \\
\text { memorizing short Quran verses. }\end{array}$ \\
\hline
\end{tabular}

\section{Singing}

During the interview, the researcher asked the participants about the learning often implemented by them in teaching Islamic Education subject and all the participants gave the same answer, namely the singing method. The participant agreed that singing activities favour long memory effect on children due to the rhythm that allows children to quickly follow and memorize a topic taught.

"The easiest way to teach these students is to sing. Play the song Omar and Hana or Didi and Friends, they are really quick to follow. Sometimes they already memorized that song"

(G1 interview)

"We always play Omar and Hana songs when we have free time in the kindergarten because they will sing a lot. When we play the songs, the students will sing along. Besides, we also play Asma ul Husna song in the morning. When we teach the students about angel, we will play song related to it. It is easy for them to memorize."

(G2 interview)

"The easiest way to teach these students is by singing, no matter what the rhythm of the song is; the students will love it because it is fun. It is normal for these children to have fun."

(G3 interview)

\section{Storytelling}

This study found that storytelling activity is also one of the activities often used by teachers in teaching Islamic Education. Two participants have frequently used this activity in their classroom during the induction phase. Participants used storytelling to introduce the content and objectives of the learning to the children. 
"When I want to start that class, I will start by telling a story. For example, if I want to teach about the history of the prophet, I will talk about the prophet and the noble qualities that the prophet has and so on."

(G2 interview)

"These students like to imagine, when I told a story at the same time I asked them to imagine. For example, I said there is a devil in the toilet because the devil likes dirty places, if you go out of the toilet without following what the teacher had taught you, later the devil will disturb you."

(G3 interview)

On the other hand, the G1 opt to use flash cards. Flash cards will be pasted on the wall so that children can review or memorize what they have learned in the classroom.

"I only use flash cards. During teaching, I told the children to do activities using flash cards. After class, I will paste the cards on the classroom wall. "

\section{Modelling}

After the interview, this study found that all the participants agreed that teachers need to set a good example for childrens. This will give a profound impact on children to always behave well as taught in the classroom.

"We want our students to do and follow what we teach, so we ourselves must set a good example to our students first."

(G1 interview)

"Another effective method is that we do it first, and then we teach the students. We make ourselves a good example to the students. For example, if we see rubbish, we shoud pick it up and throw it in the rubbish bin. We will not feel guilty if we teach the same thing to the students".

(G2 interview)

"The method that I always use is that I make myself an example to students. I speak politely and show good behavior to the students so that students will follow these examples."

(G3 interview)

\section{Constraints}

In this study, it was found that only two participants stated their problems, while the other teacher did not face any difficulties in teaching Islamic Education subject.

"I actually have the difficulty to pronounce the letter gho (回). When I want to teach the students, I felt sorry for them that they will follow my pronounciation. I am also lack of knowledge to teach Jawi letter with correct pronounciation method."

(G1 interview)

The teacher lacks of knowledge on the correct pronounciation of hijaiyah letters, while it is important to correctly pronounce hijaiyah letters as it is the basic in reading Quran. Another teacher stated the difficulty in correcting student reading related to the tajwid.

"I do not know how to correct incorrect student reading, it is difficult to read."

\section{Discussion}

(G3 interview)

This study was conducted to explore the learning activities implemented by preschool teacher in teaching Islamic Education. The results of the study found that there were several learning activities performed by the teachers in teaching which is singing and storytelling. These activities frequently used in entertainment education. Using this learning activity 
conducted in a relaxed manner and at the same time learning objectives also achieved. Previous research proved that entertainment education by storytelling and singing is easy to implement and benefit children (Ramlah, Nor \& Siti, 2016; Borhan, 2004). Similarly, the learning of Islamic Education subject needs the childrens to memorize the names of Allah which can be done by listening to the Asma ul Husna song.

In addition, the availability of multimedia technology facilities makes it easier for teachers to expose children to songs or stories installed using the latest technology. This statement is also supported by Maimun, Wan and Mohd (2017) stating that multimedia can be one of the teaching aide that can help facilitate teachers as well as attract children with variations of text, graphics and mind test interactively so that their minds grow more creatively.

According to Sofia, Kamarul and Muhammad (2016), the strategy used by Islamic Education teachers is to always practice good morals in the teaching and learning process in the classroom. This statement has been proven in this study where the teachers show a good example to the children by displaying good morals (Rosmadi \& Isa, 2019; Mohamed, 2017). This is among the methods often used by the teachers so that the teaching and learning implemented achieves the purpose of children learning.

Nevertheless, problems often arise for children who do not master a subject, especially in reading the Quran if the teachers do not have in-depth knowledge and lack of self-awareness to correct the weaknesses encountered (Hambal, 2020). This finding is supported by the study of Norizah, Abu Bakar and Zaharah (2014) on the knowledge of preschool teachers. They found that the teacher knowledge is very important in determining the desired learning outcomes. When teachers do not master the knowledge, it will complicate further learning.

\section{Conclusion}

The study focused on the learning activities used by the teachers for preschool Islamic Education subject and also become a guideline to the preschool teachers who also teach this subject. The rest of the problems that arise can be detected from the constraints that come from teachers who lack of knowledge and preparation in implementing the learning activity effectively. It is expected that the private preschool education can organize courses especially for Islamic Education subject since most of the teachers teaching the preschool Islamic Education subject are not from the field of Islamic education.

Acknowledgement

This research was supported by the grant from the Universiti Kebangsaan Malaysia GG-2019059 and GG-2020-017

\section{References}

Abd Karim, N. K., Baharudin, D. F., \& Hamdani, S. (2019). Developing an Early Childhood Islamic Education Content Based on the Concept of Tarbiyatul Awlad. Proceeding of Internasional Conference on Early Childhood Development.

Borhan, L. (2004). Teaching Islam: A Look Inside an Islamic Preschool in Malaysia. Contemporary Issues in Early Childhood, 5(3), 378-390.

Buyong, N., \& Mohamed, S. (2018). The Characteristics of Quality Kindergarten. International Seminar on Educational Issues, 54(8), 225-234.

Creswell, J. W., \& Poth, C. N. (2018). Qualitative Inquiry \& Research Design: Choosing Among Five Approaches. Edisi ke-4. California: Sage Publications. 
Hambal, M. (2020). Hadith Education in Forming Character of Early Childhood. Jurnal Pemikiran dan Pendidikan Islam, 4(1): 01-11.

Hoot, J. L., Szecsi, T., \& Moosa, S. (2003). What Teachers of Young Children Should Know about Islam. Early Childhood Education Journal, 31(2): 85-90.

Jasmi, K. A., \& Mohamed, S. (2017). Penerapan Potensi Murid Dalam Pengajaran Dan Pembelajaran Pendidikan Islam Di Prasekolah. Ulum Islamiyyah, 19, 109-128.

Kaesari, M. N. (2018). Implementasi mata pelajaran pendidikan agama Islam di sekolah Melayu tadika al-Khairiyah Thailand selatan. Tesis SKR fai 301. Fakultas Agama Islam Universitas Muhammadiyah Yogyakarta.

Maimun, A. L., Wan, N. S., \& Mohd, I. H. (2017). Tahap pengetahuan dan kesedaran guru-guru Pendidikan Islam sekolah menengah di Selangor terhadap penggunaan multimedia dalam pengajaran Pendidikan Islam. Asean Comparative Education Research Journal On Islam And Civilization (ACER-J). 1(1), 1-13.

Masnan, A. B., Anthony, Nur E. Z., \& Nur A. S. (2019). The Level of Teaching Knowledge Preschool Teachers in Malaysia. Asia-Pacific Journal of Research in Early Childhood Education, 13(2), 39-48.

Masnan, A. H., \& Radzi, N. M. M. (2015). Pengetahuan persediaan pengajaran guru prasekolah baru. Jurnal Pendidikan Awal Kanak-kanak Kebangsaan, 4, 90-108.

Mohamed, S. (2017). The Practice of Acet of Giving among the Preschool Islamic Education Teachers. International Journal of Islamic and Civilisational Studies, 4(3).

Mohamed, S., \& Jasmi, K. A. (2016). Pengetahuan guru pendidikan islam prasekolah dalam rangka pembangunan tamadun ummah. Jurnal Sains Humanika, 8(3-2).

Mohd, S. O.. \& Ahmad, Y. K. (2016). Elemen Kemahiran Berfikir Aras Tinggi (KBAT) di dalam amalan pengajaran guru Pendidikan Islam menurut Imam Ghazali. Jurnal Sultan Alauddin Sulaiman Shah, 3(2).

Norizah, T., Abu, B. N., \& Zaharah. (2014). Peningkatan kemahiran menghafaz surah dan doa kanak-kanak prasekolah melalui pendekatan berasaskan teori kecerdasan pelbagai. Journal of Islamic Education, 2(1).

Nursafra, M. Z., Mohd, I. H., Khadijah, A. R., \& Wan, A. A.. (2016). Ke arah guru Pendidikan Islam sebagai pemikir kritis. Jurnal Sains Humanika, 8:3, 9- 15.

Nur, S. A. W., Maimun, A. L., Ramlee, M., Aisyah, S., \& Dedek, F.(2017). Kefahaman al-Quran dan jawi melalui permainan bahasa bermultimedia. ASEAN Comperative Education Research Journal on Islam and Civilization (ACER-J), 1(1), 41-53.

Ramlah, J., Nor, A. R., \& Siti, F. A. (2016). Edutainment Activities among Pre-School Teacher in Gombak Area. Jurnal Pendidikan Awal Kanak-Kanak Kebangsaan, 5, 19-29

Rosmadi, I. M., \& Isa, Z. M. (2019). Essential Elements of Children's Story Books in Islamic Pedagogy based on Al-Quran to Cultivate Prosocial Behavior among Preschool Children. International Journal of Education, Psychology, 4(3), 204-214.

Sofiah, M., Kamarul, A. J., \& Muhammad, A. Z. (2016). Akhlak guru dalam pengajaran dan pembelajaran Pendidikan Islam. Journal os Southeast Asia Social Sciences and Humanities, 86( 2), 31-42.

Suhid, A., Ahmad, A. M., Sabri, S. M., \& Mohamad, A. E. (2015). Pendidikan untuk Semua: Amalannya dalam Sistem Pendidikan Islam di Malaysia. International Journal of Education and Training, 1(2), 1-7.

Yin, R. K. (1994). Case Study Research Design and Methods Fourth Edition (4 td ed.). California: SAGE Publication. 
INTERNATIONAL JOURNAL OF ACADEMIC RESEARCH IN BUSINESS AND SOCIAL SCIENCES

Vol. 11, No. 2, 2021, E-ISSN: 2222-6990 (c) 2021 HRMARS

Zhaffar, N. M., Hamzah, M. I., Razak, K. A., \& Abdullah, W. A. A. W. (2016). Ke arah guru Pendidikan Islam sebagai pemikir kritis. Jurnal Sains Humanika, 8(3). 